\title{
NILAI-NILAI PENDIDIKAN KARAKTER MENURUT ISLAM
}

\author{
Sutinah \\ Sekolah Tinggi Agama Islam Masjid Syuhada Yogyakarta
}

\begin{abstract}
Di zaman yang modern ini sangatlah penting untuk mengetahui pendidikan berkarakter, karena pendidikan sekolah saja tidak mampu menghasilkan generasi penerus bangsa seperti yang dicita-citakan pancasila, karena sering kita dengar dan kita lihat ditayangan - tayangan TV tauran antara pelajar, pelecehan sexual, pelajar terlibat narkoba, dan lain-lainnya. Untuk menyelamatkan generasi penerus bangsa maka muncul pendidikan berkarakter yang tidak hanya bertugas mencerdaskan siswa secara akademik, tetapi juga mendewasakan mental mereka dan sekaligus terjamin kepribadiannya. Mudah-mudahan pendidikan berkarakter dapat membentengi siswa dari segala macam pengaruh buruk yang ada di luar sana.

In this modern age it is important to learn about the character education, as education stand alone is not able to produce the next generation as aspired Pancasila, because often we hear and see in TV shows brawl among the students, sexual harassment, students involved in drugs, and others. To save the future generation, the emerging character education that not only served to educate students academically, but also maturing their mental and at the same time assured personality. Hopefully, character education can fortify students from all sorts of bad influences out there.
\end{abstract}

\section{A. Pendahuluan}

Orang tua dan keluarga adalah " Sekolah “ pertama bagi anak. Anak yang lahir bersih seperti kertas putih akan mendapat goresan warna dari orang tua dan orang -orang terdekat atau keluarga. Dalam perkembangan anak membutuhkan peran orang tua antara lain sebagai pemelihara kesehatan mental dan fisik, pelekat dasar kepribadian yang baik, pembimbing, 
pemberi fasilitas dan motivator untuk mengembangkan diri, menciptakan suasana nyaman dan kondusif bagi pengembangan diri anak. ${ }^{1}$

Syari'at Islam memandang, anak merupakan amanat yang dibebankan oleh Allah SWT kepada orang tuanya,karena itulah orang tua berkewajiban untuk menjaga dan memelihara serta menyampaikan amanah itu kepada yang berhak yaitu anak. Karena manusia milik Allah SWT, orang tua wajib mendidik anak melalui pendidikan agama agar anak mengenal mana yang baik dan mana yang buruk. ${ }^{2}$

Pendidikan merupakan sarana untuk mengadakan perubahan secara mendasar. Pada saat pertubuhan anak perlu di tanamkan nilai pendidikan agama sejak dini, sehingga anak akan tetap sejalan dengan fitrah nya. Jika kita lihat tayangan Televisi hampir setiap hari berita mengenai tindakan amoral anak-anak dan remaja, sebagai contoh kasus pembunuhan, kekerasan, tawuran antar pelajar. Berita lain mengabarkan bahwa kasus video porno dari 500 jenis video yang telah beredar, ternyata $90 \%$ dibuat dan dilakukan oleh remaja Indonesia yang masih bersetatus pelajar ${ }^{3}$ Kasus terbaru yang sangat menghebohkan dunia pendidikan adalah tertangkapnya seorang pejabat di salah satu Perguruan Tinggi di sebuah hotel dengan beberapa teman yang sedang berpesta Narkoba. ${ }^{4}$

Banyak yang beranggapan bahwa semua masalah yang ada dan sedang menimpa bangsa ini adalah disebabkan oleh produk pendidikan yang tidak tepat. Pendidikan hanya mengutamakan aspek kognitif dan lebih sibuk dengan urusan akademik bagaimana siswa mencapai nilai yang tinggi,terkesan kaku, penuh hafalan dan terkesan mematikan kreatifitas siswa.

Salah satu cara mengatasi masalah yang menimpa dunia pendidikan sekarang ini, pendidikan karakter mempunyai peranan penting untuk merubah sistem dan muatan

\footnotetext{
${ }^{1}$ Partini,Pengantar Pendidikan Usia Dini,(Yogyakarta: Grafindo Letera Media, 2010),hlm. 55.

${ }^{2}$ ChabibThoha, Kapita Selekta Pendidikan Islam,( Yogyakarta: pustaka pelajar offset,1996), hlm. 103

${ }^{3}$ Arismantoro, Charaacter Building, ( Yogyakarta: Tiara Wacana, 2008), hlm. 25

${ }^{4} \mathrm{Htt}$ :/news.detik.com/read/2014/11/16/145409/2749624/10/prof-m-bantah-pakai-narkoba-polisi-itu-alasansaja, diakses 20 Nopember 2014
} 
pendidikan yang telah ada. Pendidikan karakter mencetak manusia yang berakhlaq, berbudi pekerti dan berperilaku baik.berbagai konsep dan formula yang dimunculkan untuk mendorong terciptanya model pendidikan karakter .

Al-Qur'an sebagai kitab suci dan panduan hidup umat Islam juga mengandung konsep-konsep serta metode-metode pendidikan. Salah satunya ada dalam surat luqman ayat 12-19. Kerena ayat-ayat tersebut perlu untuk digali, untuk dijadikan salah satu bahan acuan, bagi umat Islam dalam rangka pembentukan karakter anak .Islam juga mengajarkan kepada pemeluknya untuk memiliki ahklak yang luhur dan mulia, agar mendapat kan kebahagiaan dalam hidupnya. Islam juga tidak mengajarkan umatnya untuk berbuat ingkar, karena perbuatan ingkar itu akan merugikan diri sendiri

Pendidikan semestinya harus dapat menyentuh berbagai aspek yaitu : jasmani, rohani, mental, moral, psikis dan fisik, jika tidak maka pendidikan tidak ubahnya seperti pengajaran yang gagal. Pendidikan karakter tidak hanya terbatas pada transformasi ilmu pengtahuan yang menyurus pada kemampuan intelektual semata, tetapi juga internalisasi nilai-nilai spiritual, religius dan moral akhlak. ${ }^{5}$ sebagai mana menurut Ibnu Sina yang dikutip oleh Abuddin Nata bahwa tujuan pendidikan harus diarahkan pada pengembangan seluruh potensi yang dimiliki seorang anak ke arah perkembangannya yang sempurna, yaitu perkembangan fisik, intelektual dan budi pekerti. ${ }^{6}$

Untuk ini semua, maka peran orang tua yang lebih utama yaitu dimulai dengan memberi nama sebagaimana Sabda Rasulullah SAW yang dikutip oleh Abu Tauhid menyebutkan: yang artinya termasuk hak anak yang menjadi tanggung jawab orang tua adalah memperbagus nama dan sopan santunnya, mengajarkannya menulis, memanah,

\footnotetext{
${ }^{5}$ Suwito Fauzan, Sejarah Pemikiran Para Tokoh Pendidikan, (Bandung: Angkasa, 2003), hlm.84

${ }^{6}$ Abudin Nata, Pemikiran Para Tokoh Pendidikan Islam,( Jakarta: PT. Grafindo Press, 2003),hlm.67
} 
berenang serta tidak memberi nafkah kecuali yang halal dan menikahkan apabila telah menemukan jodohnya. ( HR. AL-Hakim $)^{7}$

Berdasarkan keterangan diatas maka jelaslah bahwa sudah menjadi kewajiban bagi orang tua, untuk menanamkan pendidikan berkarakter yang dimulai dari rumah, agar ketika anak masuk sekolah anak sudah pernah tau paling tidak sudah pernah mendengar dari lingkungan yang terdekat terutama orang tuanya.sebagaimana pendapat Muh. Athiyah ALAbrosyi yang dikutip Abu Tauhid menegaskan bahwa: "Sesungguhnya pendidikan akhlak itu adalah jiwa dari pendidikan Islam"8

Selaras dengan masalah Akhlak para tokoh baik dari barat maupun 'Alim' ulama Timur Tengah dan tokoh pendidikan telah menyampaikan secara jelas pentingnya pendidikan akhlak dalam pendidikan. Karena akhlak harus dibangun selaras dengan perkembangan ilmu pengtahuan baik umum maupun agama.

\section{B. Pengertian Nilai}

Nilai merupakan konsep yang abstrak didalam diri manusia atau masyarakat mengenai hal-hal yang di anggap salah, benar, baik, buruk. Nilai mengarah kepada perilaku dan kepuasan dalam kehidupan sehari-hari. ${ }^{9}$ Menurut kaelan nilai adalah sesuatu yang abstrak yang biasa untuk menunjuk pada kebaikan dan keberhargaan. ${ }^{10}$ Menurut Djahiri nilai adalah harga, makna, isi dan pesan, semangat atau jiwa yang tersurat dan tersirat dalam fakta, konsep dan teori sehingga bermakna fungsional. Disini nilai difungsikan untuk mengarah, mengendalikan dan menentukan kelakuan seseorang, karena nilai dijadikan standar

\footnotetext{
${ }^{7}$ Abu Tauhid Ms, Beberapa aspek Pendidikan Islam, ( Yogyakarta; Sekretariat Jurusan Fakultas Tarbiyah IAIN Sunan Kali jaga, 1990), hlm.6

8 lbid., hlm. 8

${ }^{9}$ Muhaimin dan Abdul Mujib, Pemikiran Pendidikan Islam,(Bandung: Trigeda, 1993),hlm.110

${ }^{10}$ Kaelan, Pendidikan Pancasila, ( Yogyakarta: Paradigma, 1997), hlm.85
} 
perilaku. $^{11}$ Islam memandang nilai sebagai sebuah prinsip, standar atau kualitas yang bermanfaat dan sangat diperlukan. ${ }^{12}$ berarti nilai didasarkan pada perilaku, keindahan, keadilan dan efisiensi yang mengikat manusia yang seharusnya dijalankan dan dipertahankan.karena nilai bersifat absterak dan tidak dapat diamati dengan panca indra manusia, namun dapat terlihat dan tercermin dalam tingkah laku seseorang. Karena nilai mangarah pada perilaku dan kepuasan dalam kehidupan sehari-hari. ${ }^{13}$ Menurut pandangan Islam, nilai pada hakekatnya adalah kumpulan dari prinsip-prinsip hidup, ajaran tentang bagaimana seharusnya manusia menjalankan kehidupannya di dunia ini, yang mana antara satu prinsip dengan prinsip yang lain saling keterkaitan sehingga membentuk satu kesatuan yang utuh yang tidak dapat dipisahkan antara satu dengan yang lainnya.

\section{Ciri-Ciri Nilai}

a. Nilai itu suatu realitas abstrak dan ada dalam kehidupan manusia. Nilai yang bersifat abstrak tidak dapat diindra. Yang dapat diamati hanyalah objek yang di nilai itu, misalkan orang yang memiliki kejujuran. Kejujuran adalah nilai yang tidak bisa diraba dan dirasakan oleh panca indra.

b. Nilai memiliki sifat normatif artinya nilai mengandung harapan, cita-cita dan suatu keharusan sehingga nilai memiliki sifat ideal (dassollen). Nilai diwujudkan dalam bentuk norma sebagai landasan manusia dalam bertindak.Misalkan nilai keadilan. Semua orang berharap dan mendapatkan, berperilaku yang mencermin nilai keadilan.

\footnotetext{
${ }^{11} \mathrm{Htt} / /$ coretanseadanya.blogspot.com/2012/09/ pengertian-nilai-moral-dan-norma dalam.html, diakses tanggal 4 Desember 2014

12 http://newjoesafirablogspot.com/2012/05/pengertian-dan-konsep-nilai-dalam-islam.html.Diakses tanggal 25 November 2014. Lihat juga http://malah tentang.wordpress.com/categori/nilai-pendidikan/Dipublikasikan oleh: M. Asrori Ardiansyah

${ }^{13}$ Muhaimin dan Abdul Mujib, Op.cit., hlm.110
} 
c. Nilai berfungsi sebagai daya dorong / motivator dan manusia adalah pendukung nilai. Manusia bertindak berdasarkan dan didorongan oleh nilai yang diyakininya. Misalkan nilai ketakwaan. Adanya nilai ini menjadikan semua orang terdorong untuk bisa mencapai derajat ketakwaan. ${ }^{14}$

2. Macam-Macam Nilai

a. Nilai logika

Nilai logika adalah nilai benar salah. Sebagai contoh jika seorang siswa dapat menjawab suatu pertanyaan, ia benar secara logika. Apabila anak keliru dalam menjawab, katakan salah. Tidak bisa mengatakan anak itu buruk karena jawabannya salah, karena buruk adalah nilai moral.

b. Nilai estetika

Nilai estetika adalah nilai indah dan tidak indah. Contohnya nilai estetika adalah apabila melihat pamandangan, menonton sebuah pentas pertunjukan, atau merasakan makanan, nilai estetika bersifat subjektif. Seseorang akan senang melihat sebuah lukisan yang menurutnya indah tetapi orang lain mungkin tidak suka dengan lukisan itu.

c. Nilai etika/ moral adalah nilai baik buruk

Nilai moral adalah suatu bagian dari nilai, yaitu nilai yang menangani kelakuan baik atau buruk dari manusia. Moral selalu berhungan dengan nilai, tetapi tidak semua nilai adalah nilai moral. Moral berhungan dengan kelakuan atau tindakan manusia. Nilai moral inilah yang terkait dengan tingkah laku kehidupan seharihari. ${ }^{15}$

\footnotetext{
${ }^{14} \mathrm{http}$ ://www.isomwebs.net/2010/10/pancasila-sebagai-sumber-nilai/.Diakses tanggal 20 November 2014

${ }^{15} \mathrm{lbid} . \mathrm{hlm}$
} 


\section{Pendidikan Karakter}

\section{Makna Pendidikan Karakter}

Kata pendidikan karakter terdiri dari dua suku kata, yaitu pendidikan dan karakter. Kedua kata yang memiliki makna sendiri-sendiri. Pendidikan sendiri merupakan terjemahan dari education, yang kata dasarnya adalah educate, yang berarti mengembangkan dari dalam, mendidik, melaksanakan hukum kegunaan ${ }^{16}$.

Makna lain dikatakan bahwa kata education berasal dari bahasa latin educare yang berarti melatih atau menjinakkan ( seperti dalam konteks manusia melatih hewan liar menjadi semakin jinak sehingga bisa diternakkan), dan menyuburkan ( membuat tanah lebih menghasilkan karena tanah di olah dan digarap). ${ }^{17}$ Berdasarkan pengertian diatas pendidikan merupakan sebuah proses yang membantu menumbuhkan, mendewasakan, mengembangkan, menjadikan yang liar menjadi jinak dan tertata.

Berdasarkan berbagai pengertian, pendidikan pada prinsipnya adalah sama, yaitu bagaimana seseorang memberikan bimbingan, pengarahan, sehingga menjadikan seseorang dewasa dan bisa dikendalikan.dalam kamus bahasa indonesia menyebutkan karakter diartikan sebagai tabiat, watak, sifatsifat kejiwaan, akhlak atau budi pekerti yang membedakan seseorang dengan yang lain, yang meliputi hal-hal seperti perilaku, kebiasaan, kesukaan, ketidak sukaan, kemampuan, kecenderungan, potensi, nilai-nilai, dan pola-pola pemikiran. $^{18}$

\footnotetext{
${ }^{16}$ Sutrisno, Pembaharuan dan pengembangan Pendidikan Islam,( Yogyakarta: Fadilatama, 2011), hlm.3

${ }^{17}$ Doni Koesoema, Pendidikan Karakter, Strategi Mendidik Anak di Zaman Global, (Jakarta: Grasindo, 2011), hlm.53

${ }^{18}$ W.J.S.Purwadarminta, Kamus Umum Bahasa Indonesia, ( Jakarta: Balai Pustaka.1976),hlm.521
} 
Pendidikan karakter adalah suatu bentuk pengarahan dan bimbingan supaya seseorang mempunyai tingkah laku yang baik sesuai dengan nilal-nilai kebaikan dan kebenaran serta kemaslahatan dalam kehidupan sehari-hari.

\section{Tujuan Pendidikan Karakter}

Para tokoh pendidikan barat yang terkenal seperti Klipatrick, Lickona, Brooks dan Goble mengusung kembali konsep dan misi yang dibawa oleh Nabi Muhammad SAW . bahwa moral, akhlak atau karakter adalah pendidikan. ${ }^{19}$ Secara umum tujuan pendidikan adalah sama yaitu untuk menjadikan manusia lebih baik dan dapat mengembangkan segala kemampuannya. UU No.20 tahun 2003 tentang sistem pendidikan Nasional, menyebutkan bahwa tujuan pendidikan ialah untuk mengembangkan kemampuan dan membentuk watak serta peradaban bangsa yang bermartabat dalam rangka mencerdaskan kehidupan bangsa, bertujuan untuk berkembangnya potensi peserta didik agar menjadi menusia yang beriman dan bertaqwa kepada Tuhan yang Maha Esa, berakhlak mulia, sehat, berilmu, cakap, kreatif, mandiri, dan menjadi warga Negara yang demokratis serta bertanggung jawab. ${ }^{20}$

Pendidikan berkarakter tercermin dari beberapa aspek yaitu :

a. Mengembangkan potensi kalbu/ nurani/ afektif peserta didik sebagai manusia dan warga Negara yang mempunyai karakter bangsa.

\footnotetext{
${ }^{19}$ Abdu Majid, dkk, Op.cit, hlm.30

${ }^{20}$ Barmawi dan M.Arifin, Strategi dan Kebijakan Pembelajaran Pendidikan Berkarakter, ( Yogyakarta: Ar-Ruzz Media, 2012), hlm.45
} 
b. Mengembangkan kebiasaan dan perilaku peserta didik yang terpuji dan sejalan dengan nilai-nilai universitas dan tradisi budaya bangsa yang relegius.

c. Menanamkan jiwa kepemimpinan dan tanggung jawab peserta didik sebagai generasi penerus bangsa.

d. Mengembangkan kemampuan peserta didik menjadi manusia yang mandiri, krearif, dan berwawasan kebangsaan

e. Mengembangkan lingkungan kehidupan sekolah sebagai lingkungan belajar yang aman, jujur, penuh kreativitas dan persahabatan, dan dengan rasa kebangsaan yang tinggi serta penuh kekuatan. ${ }^{21}$

Kesimpulannya bahwa pendidikan karakter bertujuan untuk meningkatkan mutu serta hasil pendidikan yang mangarah kepada terbentuknya manusia yang berkarakter/ berakhlak mulia, dan mampu mandiri dalam meningkatkan dan mengembangkan potensinya sehingga dapat mengimplementasikan nilai-nilai karakter / akhlak mulia di dalam kehidupan sehari-hari.

3. Pilar Pendidikan Karakter

sebagaimana pendapat Heritage Foundation yang dikutip oleh Abdul Majid merumuskan ada sembilan karakter dasar yang menjadi tujuan pendidikan :

a. Cinta kepada Allah dan semesta beserta isinya.

b. Tanggung jawab disiplin dan mandiri

c. Jujur

${ }^{21}$ Zubaedi, Op.cit.hlm.18 
d. Hormat dan santun

e. Kasih sayang, peduli, dan kerja sama

f. Percaya diri,kreatif, kerja keras dan pantang menyerah

g. Keadilan dan kepemimpinan

h. Baik dan rendah hati

i. Toleransi, cinta damai, dan persatuan. ${ }^{22}$

Ari Ginanjar Agustian dengan teori ESQ menyampaikan bahwa setiap karakter positif sesungguhnya merujuk pada sifat-sifat mulia Allah, yaitu alAsma' al-Husna. Sifat-sifat dari nama Allah inilah yang menjadi sumber inspirasi setiap karakter positif.sehingga Ari Ginanjar merangkumnya menjadi tujuh karakter dasar yaitu : a.Jujur, b.Tanggung jawab,c. Disiplin, d.Visioner, e. Adil,f. Peduli, g. Kerja sama. ${ }^{23}$

4. Pendidikan Karakter dalam Islam

Manusia adalah makhluk yang dapat mendidik dan di didik, karena manusia dikarunia akal, sedangkan mahluk lain tidak.manusia mempunyai potensi yang dapat menjadi objek dan subjek pengembangan diri, sehingga manusia mampu mengemban tugasnya didunia ini, yaitu menjadi khalifah.potensi seseorang tidak bisa berkembang tampa ada ransangan dari luar. Maka dari itu manusia membutuhkan pendidikan, yang berpungsi sebagai ransangan dari luar dirinya.

Pendidikan adalah sebuah aktivitas manusia yang memiliki maksud mengembangkan individu sepenuhnya yang berkisar antar dua demensi nilai, yaitu nilai-nilai ilahiyah dan nilai-nilai insaniyah. ${ }^{24}$ Pendidikan Islam

${ }^{22}$ Abdul Majid, dkk, Op.cit, hlm.42

23 Ibid. 42

${ }^{24}$ Abdul Majid, dkk, Op. Cit, hlm.92 
merupakan pendidikan yang bersumber dari al-qur'an dan al-Hadits, maka pendidikan karakter sebagai bagian dari pendidikan Islam juga harus didasarkan pada al-qur'an dan hadits. Karena alqur'an memberikan tuntunan kepada manusia tentang bagaimana mendidik pendidikan karakter pada anak.

Secara garis besar menurut Al- Qur'an dan hadits terdapat langkahlangkah pendidikan karakter yaitu :

a. Pendidikan pra konsepsi

Pendidikan ini adalah upaya persiapan pendidikan yang dilakukan oleh seseorang semenjak ia mulai memilih atau mencari jodoh sampai pada saat terjadinya pembuahan dalam rahim seorang ibu. Dalam hal ini perlu persiapan; pertama adalah memilih jodoh. $^{25}$ dalam memilih jodoh seseorang dianjurkan untuk memilih pasangan yang memungkinkan untuk diajak hidup berumah tangga, sebagaimana firman Allah dalam al-Qur'an dalam surat al- Baqarah ayat 221 yang artinya : "Dan janganlah kamu menikahi wanita-wanita musyrik, sebelum mereka beriman. Sesungguhnya wanita budak yang mukmin lebih baik dari wanita musyrik, walaupun ia menarik hatimu. Dan janganlah kamu menikahkan orang-orang musyrik ( dengan wanita-wanita mukmin) sebelum mereka beriman. Sesungguhnya budak yang mukmin lebih baik dari orang musyrik, walaupun Dia menarik hatimu. Mereka mengajak keneraka, sedang Allah mengajak ke surga dan ampunan dengan izinnya. Dan Allah menerangkan ayat-ayatnya ( perintahperintah Nya) kepada manusia supaya mereka mengambil pelajaran. ${ }^{26}$

\footnotetext{
${ }^{25}$ http://muhfathurrohman.wordpress/2012/09/09/ Pendidikan-Karakter-dalam-perspektif-islam.Diakses 30 Desember 2014.

${ }^{26}$ Departemen Agama, Op.,Cit., hlm.54
} 
b. Tahapan pendidikan pra natal

pendidikan pre- natal adalah upaya persiapan pendidikan yang dilakukan oleh kedua orang tua pada saat anak masih dalam kandungan sang ibu. Pada fase ini ada beberapa tahap yang bisa ditempuh dalam mempersiapkan dan membentuk karakter anak.

Sebagai contoh adalah peristiwa yang dialami oleh keluarga Imran yang termuat dalam surat Ali- Imran. Dijelaskan bahwa keluarga Imran sangat menginginkan adanya seorang keturunan, walaupun dari segi umur mereka adalah orang yang sudah berumur lanjut. Ada dua yang dapat kita ambil, pertama Doa yang sungguh-sungguh kepada Allah SWT. Mengharapkan adanya keturunan. Kedua mereka bernadzar baik, yaitu kelak anak yang lahir akan di didik dengan pendidikan agama.

Dalam pendidikan modern banyak yang menyebutkan bahwa kondisi dan keadaan ibu pada masa mengandung sangat berhubungan dengan keadaan psikologis anak. Anak mampu menangkap dan memahami situasi di luar rahim. Oleh karena itu banyak yang berpendapat dengan memperdengar nada ataupun musik yang bernada teratur akan membentuk karakter yang teratur pula.

c. Pendidikan post- natal

Fase ini adalah memberikan pendidikan pada saat anak sudah dilahirkan ke dunia. Menurut Muhammad Fathurrohman dalam makalahnya pendidikan yang harus diberikan kepada anak, pertama pendidikan jasmani yaitu mempersiapkan anak agar tumbuh menjadi 
manusia yang ideal. Kedua pendidikan aqidah. Pendidikan aqidah merupakan pendidikan yang diberikan pertama kali semenjak anak lahir kedunia,ke tiga Pendidikan Syariah ( ibadah ) Anak diberikan pengtahuan tentang kewajiban beribadah kepada Allah dan tatacara melaksanakannya. Ke empat Pendidikan akhlak merupakan pendidikan yang berperan penting dalam pembentukan emosional dan kepribadian manusia. ${ }^{27}$

Nilai - nilai pendidikan karakter dalam Al-Qur'an :

1. Syukur

Secara bahasa syukur mem punyai arti pujian, secara istilah yaitu mentasarufkan segala kenikmatan yang telah diberikan Allah sesuai dengan fungsinya. Diawali dari lubuk hati yang paling dalam betapa besarnya nikmat dan anugrahnya sehingga terdorong untuk memujinya dengan ucapan sambil melaksanakannya. ${ }^{28}$

“ Allah SWT berfirman dalam surat An-Nahl ayat 14, yang artinya : Dan jika kamu menghitung-hitung nikmat Allah, niscaya kamu tak dapat menentukan jumlahnya. Sesungguhnya Allah benar-benar Maha Pengampun lagi Maha penyayang “. Q.S. An- Nahl 14). ${ }^{29}$

Orang yang selalu bersyukur akan diberikan kehidupan yang tenteram, damai, tenang dan bahagia serta terhindar dari fitnah dan azab dunia dan akhirat . Sebagaimana firman Allah SWT dalam Surat Ibrahim ayat 7 yang artinya " Dan (ingatlah juga), tatkala Tuhanmu memaklumkan; Sesungguhnya jika kamu bersyukur, pasti kami akan menambah ( nikmat)

\footnotetext{
${ }^{27}$ http://muhfathurrohman. Wordpress. Com/2012/09/09/ pendidikan-karakter-dalan-perspektif-islam. Diakses 30 Desember 2014

28 Ibid, hlm.294

${ }^{29}$ Departeman Agama, Al- Qur'an dan terjemahnya, ( Surabaya: Al-Hidayah,2002), hlm.404
} 
kepadamu, dan jika kamu mengingkari ( nikmat-ku), Maka sesungguhnya Azabku sangat pedih." (Q.S. Ibrahim : 7). ${ }^{30}$

\section{Aqidah}

Aqidah, dasar dari keimanan seseorang yang harus ditanam kepada anak sejak dini , hal ini dapat kita lihat dalam Surat Lukman ayat 13 Yang artinya " Hai anakku, janganlah kamu mempersekutukan Allah, sesungguhnya mempersekutukan Allah adalah benar-benar kezaliman yang besar “. Quraish shihab menyebutkan Lukman memulai nasehatnya dengan menekankan akan perlunya menghindari kesyirikan. Larangan ini sekaligus pengajaran tentang keesaan Allah. Redaksi pesan larangan untuk menyekutukan Allah untuk menekankan meninggalkan sesuatu yang buruk sebelum melaksanakan yang baik. ${ }^{31}$

3. Berbuat baik kepada kedua orang tua

Berbakti kepada orang tua dalam Surat Luqman, ini menunjukkan betapa pentingnya hormat kepada orang tua, Sehingga masuk urutan kedua setelah pengabdian kepada Allah SWT. ${ }^{32}$ Pesan ini disebabkan karena pengorbanan seorang ibu yang telah mengandung, melahirkan kemudian menyusui anak selama dua tahun. Karena begitu besar jasa orang tua, seorang anak harus berbakti kepada keduanya.

4. Sholat.

Sholat memiliki kedudukan yang utama dalam keseluruhan ibadah kepada Allah, sholat menjadi penting karena : Pertama sholat sebagai tiang agama,kedua sholat sebagai amal ibadah yang membedakan antara umat Islam dengan orang kafir Sebagaimana sabda Nabi SAW : Yang artinya “ dikisahkan dari Abu Ghasnal Misma’i dari Dhahak bin Mukhlad dari Ibnu Juraij berkata : dikabarkan kepadaku dari Abu Zubair bahwasanya Ia mendengar Jabir

\footnotetext{
30 Ibid, hlm.385

${ }^{31}$ Quraish shihab, Op.,Cit., hlm.298

32 Ibid, hlm.301
} 
bin Abdillah berkata : Aku mendengar Rasullulah SAW bersabda : Perbedaan antara seorang mukmin dengan syirik dan kafir adalah meninggalkan sholat. ${ }^{33}$

\section{Amar Ma'ruf Nahi Mungkar}

Ma'ruf adalah yang baik menurut pandangan umum suatu masyarakat selama sejalan dengan kebajikan sedangkan mungkar adalah suatu yang dinilai buruk oleh masyarakt serta bertentangan dengan nilai-nlai Ilahi. ${ }^{34}$ Sebagaimana disabdakan oleh Nabi Muhammad SAW, Yang artinya : “ Diriwayatkan dari Abi Sa'id Radhiyallahu 'anhu Aku telah mendengar Rasulullah SAW bersabda : Barang siapa diantara kamu melihat kemungkaran, hendaklah ia mencegah kemungkaran itu dengan tangan atau kekuasaannya, jika tidak mampu, hendaklah ia mencegah dengan lisannya, kemudian jika tidak mampu maka hendaklah ia mencegah dengan hatinya. Yang demikian adalah selemah-lemah iman. ${ }^{35}$

\section{Sabar.}

Sabar merupakan suatu kekuatan atau daya positif yang mendorong untuk menunaikan kewajiban, dan juga satu kekuatan yang menghalangi seseorang untuk melakukan kejahatan. Banyak ayat al-Qur'an maupun hadits yang menganjurkan untuk bersabar, ada yang berupa perintah secara tegas untuk bersabar, sebagaimana Firman Allah dalam surat Al-Anfal ayat 46 yang artinya “ Dan taatlah kepada Allah dan Rasulnya dan janganlah kamu berbantahbantahan, yang menyebabkn kamu menjadi gentar dan hilang kekuatanmu dan bersabarlah. Sesungguhnya Allah beserta orang-orang yang sabar.( Q.S. Al- Anfal : 46) ${ }^{36}$

\section{Larangan bersikap sombong}

\footnotetext{
${ }^{33}$ Sayyid Sabiq, Fiqh Sunnah Jilid I, Penerjemah Nor Hasanuddin, ( Jakarta: Pena Pundi Aksara, 2007),hlm. 128

${ }^{34}$ Quraish Shihab, Op., Cit., hlm.309

${ }^{35}$ Ahmad Mudjab Mahalli, Hadits-Hadits Muttafaq 'Alaih, ( Jakarta Timur : Prenada Media, 2004) hlm. 53

${ }^{36}$ Departeman Agama, Al-Qur’an dan terjemah, hlm. 268
} 
Sombong biasa disebut dengan takabur berarti sifat dan sikap yang merendahkan orang lain dan bisa menolak al-haqq ( kebenaran). Dalam hal ini Al-Biqa'i menyebutkan sebagaimana di tulis oleh Quraish shihab bahwa asal muasal kejadian manusia dari sari pati tanah sehingga hendaknya jangan menyobongkan diri dan berjalan dengan angkuh. ${ }^{37}$

Al- Asyur berpendapat bahwa bumi adalah tempat berjalan semua orang yang kuat ,yang lemah,yang kaya, yang miskin, penguasa dan rakyat jelata. Mereka semua adalah sama, sehingga tidak wajar bagi pejalan yang sama menyombongkan diri dan merasa melebihi orang lain. ${ }^{38}$

Sifat kekaguman dan membanggakan diri dapat menimbulkan kesombongan dan ke angkuhan. Salah satu penyakit hati yang sangat mencelakan dan sulit di hindari. Dalam AlQur'an sudah tertera larangan dan ancaman serta bahaya yang akan ditimbulkan dari sifat takabur ini. Jika seseorang sudah melekat pada sifat ini., maka sesegera mungkin untuk mengobatinya dan segera menghindarinya, karena sifat ini sangat merugikan diri sendiri maupun orang lain.

Penutup

Berdasarkan uraian diatas maka dapat di jelaskan bahwa nilai-nilai pendidikan berkarakter dalam Al-Qur'an menurut Islam adalah : Pertama Syukur, kedua Aqidah, ketiga Berbuat baik kepada orang tua, keempat Sholat, Kelima Amar ma'ruf nahimungkar, keenam Sabar, Ketujuh Larangan bersikap sombong.Menurut Muhammad Fathurrohman Pertama Pendidikan jasmani, Kedua Pendidikan Aqidah, Ketiga PendidikanSyariah ( ibadah), Ke empat Pendidikan Akhlak. pendidikan Akhlak yang tidak kalah pentingnya karena ini sangat berpengaruh dalam pembentukan emosional dan keperibadian.

\footnotetext{
37 Ibid, hlm. 268

38 Ibid, hlm. 269
} 


\section{DAFTAR PUSTAKA}

Abudin Nata, Pemikiran para tokoh pendidikan Islam, Jakarta : PT. Grafindo Press,2003 Ahmad Mudjab Mahalli, Hadis-Hadis Muttafaq ‘Alaih, Jakarta Timur: Prenada Media, 2004 Chabib Thoha, Kapita Selekta Pendidikan Islam, Yogyakarta; Pustaka Pelajarn Offset, 1996 Depag, Al-Qur'an dan terjemah, Semarang : CV Toha Putra, 1996

Kaelan, Pendidikan Panca Sila, Yogyakarta: Paradigma,1997

Muhaimin dan Abdul Mujib, Pemikiran Pendidikan Islam, Bandung: Trigeda, 1993

Partini, Pengantar Pendidikan Usia Dini, Yogyakarta: Grafindo Litera Media, 2010

Quraish Shihab, Tafsir Al-Mishbah Pesan Kesan dan keserasian al- Qur'an volume 10, Jakarta: LeterHati, 2007

Sayyid Sabiq, Fiqh Sunnah Jilid I, Penerjemah Nor Hasanuddin,Jakarta: Pena Pundi Aksara, 2007

Sutarjo Adisusilo, Pembelajaraan Nilai Karakter, Jakarta: Raja Grafindo Persada,2013 Suwito Fauzan, Sejarah Pemikiran Para tokoh Pendidikan, Bandung : Angkasa, 2003 W.J.S. Purwadarminta, Kamus Umum Bahasa Indonesia, Jakarta: Balai Pustaka, 1976 http://muhfathurrohman. Wordpress.com/2012/09/09 pendidikan- karakter-dalam-perspektifislam

http://coretanseadanya.blogspot.com/2012/09/pengertian-nilai-moral-dan-norma- dalam html http//newjoesafirablogspot.com/2012/05/pengertian-dan-konsep-nilai--dalam-islam.html http://muhfatthurrohman.wordpress.com/2012/09/09/pendidikan-karakter-dalam-perspektif$\underline{\text { islam }}$ hyyp://news.detik.com/read/2014/11/16/145409/2749624/10/prof-m-bantah-pakai-narkobapolisi-itu-alasan-saja 
